\title{
HEALTH OF THE SCHOOLCHILD
}

\author{
BY \\ VERA NORRIS \\ Department of Medical Statistics, University of Birmingham
}

Though it has long been customary for schools, whether supported by private or by public funds, to maintain attendance and medical records, little use has been made of them to evaluate the causation of absenteeism in schoolchildren. This communication is the result of an ad hoc survey of the medical and absence records kept in a girls' grammar school, which was originally undertaken to ascertain the effects of long-distance travelling on the health and educational progress of the schoolchild. Analysis of the data disclosed unforeseen variables, the effect of which makes it impossible to draw decisive conclusions upon that subject, but it may not be unprofitable to examine how far they can provide answers to the following questions:

(i) What information is obtainable from school records as they are maintained at present?

(ii) What is the use of information so obtained ?

(iii) What improvements in the design of school records would yield more adequate and accurate information regarding the health of adolescents?

The school concerned, housed in modern buildings in a pleasant residential area, has a high reputation both academically and socially. Entrance places, for which there is keen competition, are awarded on the results of various examinations. The absence experience may not be typical of all schools providing further education for children over the age of fifteen.

\section{Avallable Records}

The following records, kept as a routine, were available:

(1) Ministry of Education registers;

(2) Registers recording reasons for absence;

(3) Medical record cards.

(1) The Ministry of Education registers provided information for each pupil regarding the frequency of absence and the duration of each absence.

(2) Information regarding causation was available for 2 years (1946-47, 1947-48). As a general rule the school authorities did not require certification of short-term illnesses, i.e. less than 3 days, by medical practitioners except in unusual circumstances, and in many cases notes from the parents were accepted. Consequently, it was only justifiable to classify the causes of absence under these broad headings: 
(a) acute diseases of the respiratory system, including the miscellaneous respiratory syndromes variously described as cold in the head, influenza, cough, chill, etc.

(b) other medical ailments including specific infectious diseases, rheumatism, sickness, dysmenorrhoea, etc.

(c) miscellaneous causes other than illness, e.g. transport difficulties, external examinations for scholarships, social and family reasons, etc.

(d) unspecified and unrecorded causes.

(3) The medical records provided information respecting:

(a) medical history,

(b) height and weight,

(c) visual defects,

(d) contemporary physical condition,

(e) menarche.

Each girl on entry to the school at approximately 11 years of age was examined by the school doctor and at this examination the medical record was initiated. After 4 or 5 years a further medical examination was made. Girls whose physical condition was not considered satisfactory by either the parents or the teachers had supplementary examinations during the intervening period.

Average heights and weights in the various age groups have been calculated from every available observation, so that two observations of height and weight have been recorded for every girl (200 in all) who, at the time of the survey, had had two medical examinations. Unless a girl was menstruating at the time of her first examination no record of age of onset was made until the second examination.

In noting records of previous illness, infectious diseases of childhood were ignored unless some complication (e.g. broncho-pneumonia) had arisen as a result, for it was felt that in many cases the parents would not recall mild attacks of infectious disease in early childhood.

\section{Absence Rates}

To describe absence rates the following definitions will be necessary:

Occasion of Absence A series of consecutive days during which the pupil was absent from school. Duration of Absence The number of consecutive days absent including week-ends when an occasion of absence began in one week and continued to the next.

Absentee .. .. A pupil who began an absence during a specified period (e.g. term or week). Short-term Absence An absence of less than three days.

The summer terms were disregarded because so many absences were due to holidays with parents, examinations, and other activities sanctioned by the school.

Information was available regarding the cause of absence among 369 girls for five terms, Spring and Autumn 1946, Spring and Autumn 1947, and Spring 1948.

Tables I - III show the following absence rates for each of the five terms:

I. Average number of absences for each pupil.

II. Average number of days of disability for each pupil.

III. Average duration of each occasion of absence.

\section{Respiratory Disease as a Major Cause of Disability}

These Tables show that respiratory disease was ostensibly the most frequent cause of absence, that it caused the greatest number of days of disability, and (with the exception of two terms when there were epidemics of measles and scarlet 
TABLE I

Average Number of Occasions of Absence for Each Pupil

\begin{tabular}{|c|c|c|c|c|c|c|c|c|}
\hline \multirow{2}{*}{\multicolumn{3}{|c|}{ Cause of Absence }} & & \multicolumn{5}{|c|}{ Term } \\
\hline & & & & $\underset{1946}{\text { Spring }}$ & $\begin{array}{c}\text { Autumn } \\
1946\end{array}$ & $\begin{array}{c}\text { Spring } \\
1947\end{array}$ & $\underset{1947}{\text { Autumn }}$ & $\begin{array}{c}\text { Spring } \\
1948\end{array}$ \\
\hline $\begin{array}{l}\text { Respiratory Disea } \\
\text { Unspecified } \\
\text { Other Medical } \\
\text { Non-medical }\end{array}$ & $\begin{array}{l}\text { case } \\
\ldots \\
\ldots \\
\ldots\end{array}$ & $\begin{array}{l}\ldots \\
\cdots \\
\cdots \\
\cdots\end{array}$ & $\begin{array}{l}. \\
\cdots \\
\cdots \\
\cdots\end{array}$ & $\begin{array}{l}0 \cdot 707 \\
0 \cdot 293 \\
0 \cdot 233 \\
0 \cdot 043\end{array}$ & $\begin{array}{l}0.463 \\
0.233 \\
0.295 \\
0.249\end{array}$ & $\begin{array}{l}0 \cdot 783 \\
0 \cdot 481 \\
0 \cdot 387 \\
0 \cdot 157\end{array}$ & $\begin{array}{l}0.601 \\
0.458 \\
0.243 \\
0.392\end{array}$ & $\begin{array}{l}0 \cdot 351 \\
0 \cdot 305 \\
0 \cdot 298 \\
0 \cdot 122\end{array}$ \\
\hline Total & . & . & .. & $1 \cdot 276$ & $1 \cdot 241$ & $1 \cdot 807$ & $1 \cdot 694$ & $1 \cdot 077$ \\
\hline
\end{tabular}

TABLE II

Average Number of Days of Disability for Each Pupil

\begin{tabular}{|c|c|c|c|c|c|c|}
\hline \multirow{2}{*}{\multicolumn{2}{|c|}{ Cause of Absence }} & \multicolumn{5}{|c|}{ Term } \\
\hline & & $\begin{array}{l}\text { Spring } \\
1946\end{array}$ & $\underset{1946}{\text { Autumn }}$ & $\begin{array}{c}\text { Spring } \\
1947\end{array}$ & $\underset{1947}{\text { Autumn }}$ & $\begin{array}{c}\text { Spring } \\
1948\end{array}$ \\
\hline $\begin{array}{lc}\text { Respiratory Disease } \\
\text { Unspecified } & \ldots \\
\text { Other Medical } & \ldots \\
\text { Non-medical } & \ldots\end{array}$ & $\begin{array}{l}\cdots \\
\cdots \\
\cdots\end{array}$ & $\begin{array}{l}3 \cdot 157 \\
0 \cdot 919 \\
0 \cdot 908 \\
0 \cdot 122\end{array}$ & $\begin{array}{l}1 \cdot 274 \\
0 \cdot 358 \\
0 \cdot 593 \\
0 \cdot 547\end{array}$ & $\begin{array}{l}3 \cdot 063 \\
1 \cdot 022 \\
2 \cdot 269 \\
0 \cdot 299\end{array}$ & $\begin{array}{l}1 \cdot 812 \\
0.871 \\
0 \cdot 552 \\
0.951\end{array}$ & $\begin{array}{l}1 \cdot 274 \\
0 \cdot 888 \\
1 \cdot 34 \\
0 \cdot 27\end{array}$ \\
\hline Total & .. & $5 \cdot 106$ & $2 \cdot 772$ & $6 \cdot 653$ & $4 \cdot 187$ & $3 \cdot 772$ \\
\hline
\end{tabular}

TABLE III

Average Number of Days of Disability for Each Occasion of Absence

\begin{tabular}{|c|c|c|c|c|c|c|c|}
\hline \multirow{2}{*}{\multicolumn{3}{|c|}{ Cause of Absence }} & \multicolumn{5}{|c|}{ Term } \\
\hline & & & $\begin{array}{c}\text { Spring } \\
1946\end{array}$ & $\underset{1946}{\text { Autumn }}$ & $\begin{array}{l}\text { Spring } \\
1947\end{array}$ & $\underset{1947}{\text { Autumn }}$ & $\begin{array}{c}\text { Spring } \\
1948\end{array}$ \\
\hline $\begin{array}{lc}\text { Respiratory Disease } \\
\text { Unspecified } & . . \\
\text { Other Medical } & \ldots \\
\text { Non-medical } & .\end{array}$ & $\begin{array}{l}\ldots \\
\cdots \\
\cdots\end{array}$ & $\begin{array}{l}. . \\
. \\
. \\
.\end{array}$ & $\begin{array}{l}4 \cdot 46 \\
4 \cdot 13 \\
3 \cdot 9 \\
2 \cdot 81\end{array}$ & $\begin{array}{l}2 \cdot 75 \\
1 \cdot 53 \\
2 \cdot 01 \\
2 \cdot 2\end{array}$ & $\begin{array}{l}3 \cdot 91 \\
2 \cdot 13 \\
5 \cdot 86 \\
1 \cdot 91\end{array}$ & $\begin{array}{l}3 \cdot 02 \\
1 \cdot 9 \\
2 \cdot 27 \\
2 \cdot 42\end{array}$ & $\begin{array}{l}3 \cdot 63 \\
2 \cdot 91 \\
4 \cdot 49 \\
2 \cdot 2\end{array}$ \\
\hline Total & .. & .. & $4 \cdot 0$ & $2 \cdot 23$ & $3 \cdot 68$ & $2 \cdot 47$ & $3 \cdot 5$ \\
\hline
\end{tabular}

fever) that the average duration of absence caused by respiratory disease was longer than for any other cause. During the five terms there were 2,379 occasions of absence, of which 990 (42 per cent.) were due to respiratory disease. The total number of days of disability during this period was 7,610, of which 3,432 (45 per cent.) were due to respiratory disease. 
Table IV shows the frequency of absences of varying length. Comparison of the frequency with which respiratory disease causes short-term absences with the frequency of such absences due to all other causes shows that respiratory disease produces a significantly smaller proportion of short-term absences (Table V). A similar result is obtained if absences due to respiratory disease are compared with absences due to other medical causes.

TABLE IV

Distribution of Absences by Duration and Cause (total of five terms)

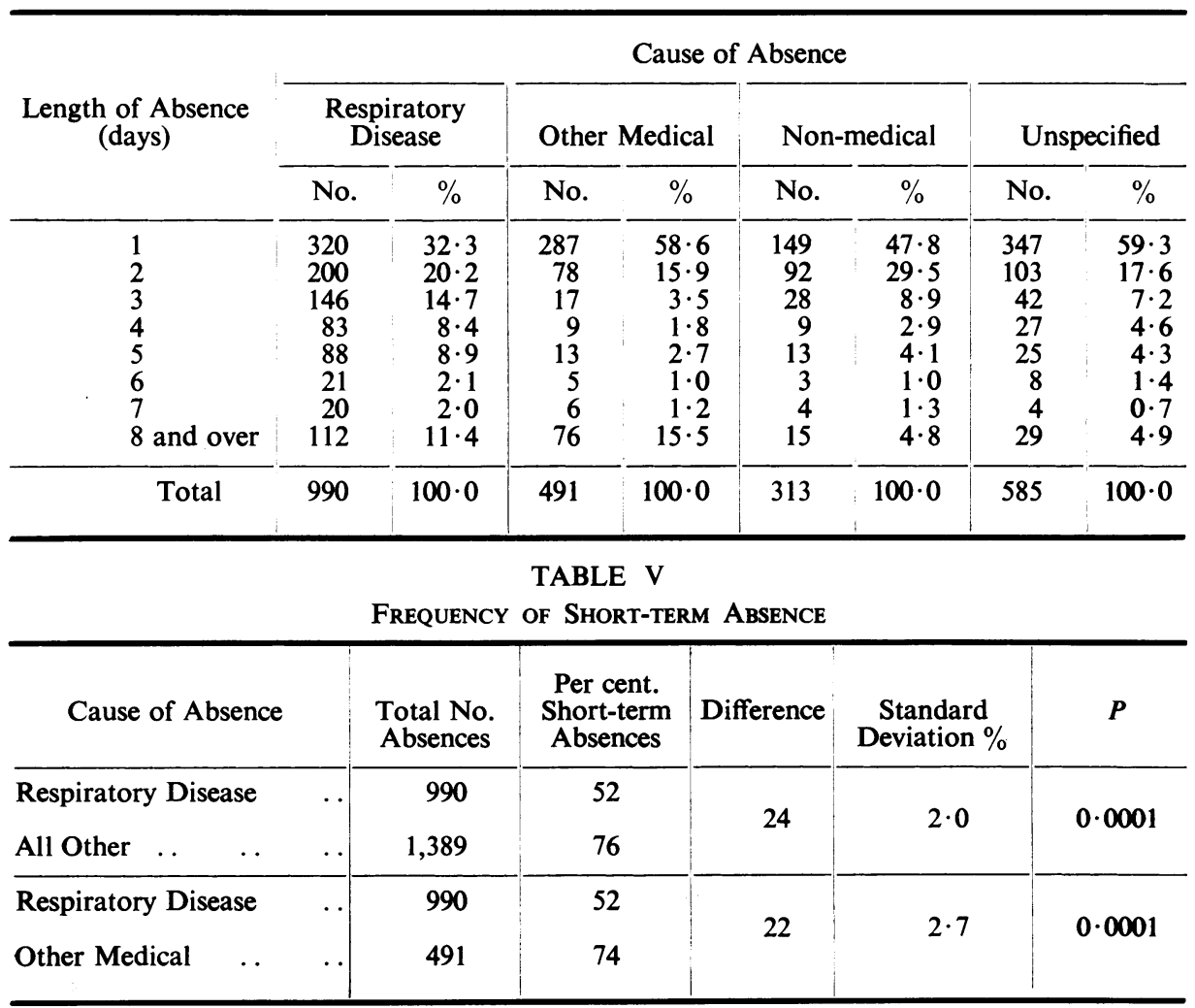

Seemingly, therefore, respiratory disease is a major cause of absenteeism, not only by virtue of its frequency but also because it is the most predominant cause of long-term absences unlikely to be due to malingering or truancy. Absentee rates, calculated for each week in the five terms to disclose terminal variations in absence, are shown graphically in Fig. 1. The peak rate in the 8th week of the Spring term, 1947 , was due to exceptionally hard weather conditions and a grave fuel shortage. The peak in the 8th week of the Autumn term, 1947, was due to a transport strike. Except in such unusual circumstances the absentee rates for all causes closely follow the pattern of those due to respiratory disease. 
FIG. 1.-Weekly absentee rates for five terms.
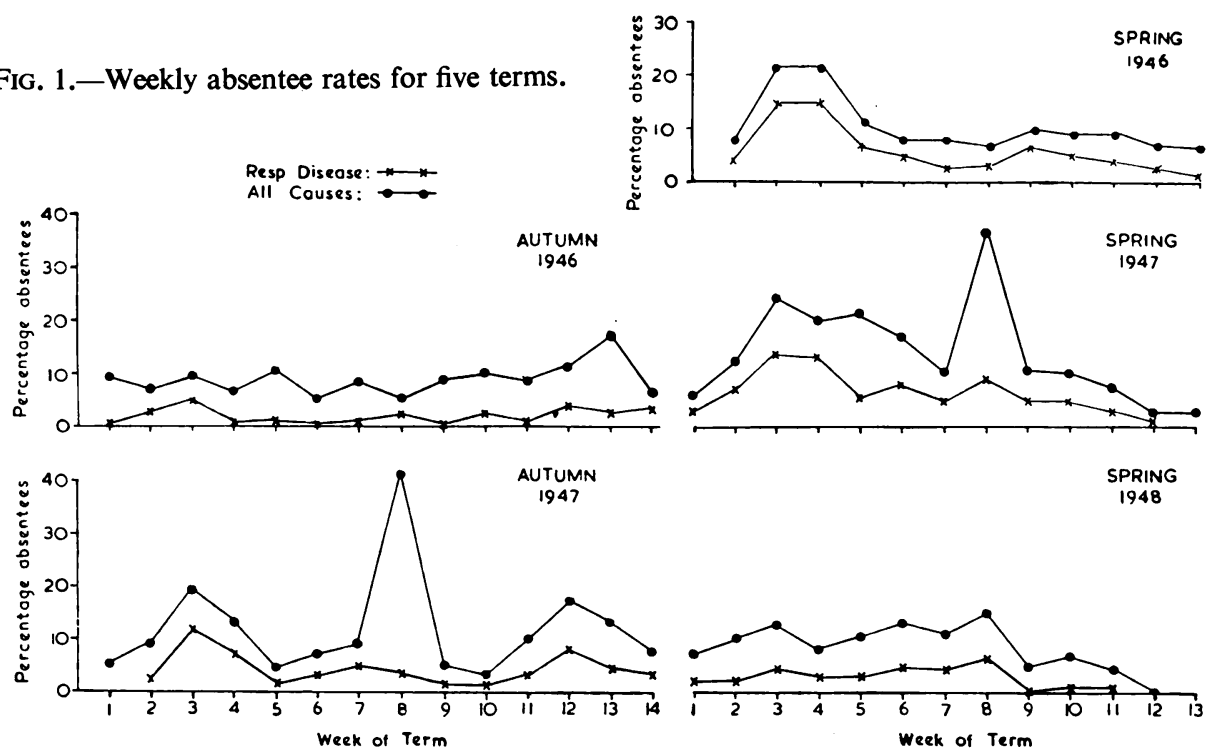

Effect of Medical Disabilities on Absence

In the medical records of 297 girls, 73 (24 per cent.) gave a history of some medical disability other than visual or postural defects (Table VI); 34 per cent. suffered from visual defects which were recorded at one or both of the medical examinations.

TABLE VI

Disabilities Recorded in Medical Histories of Girls present in the SchOOL, 1945/46

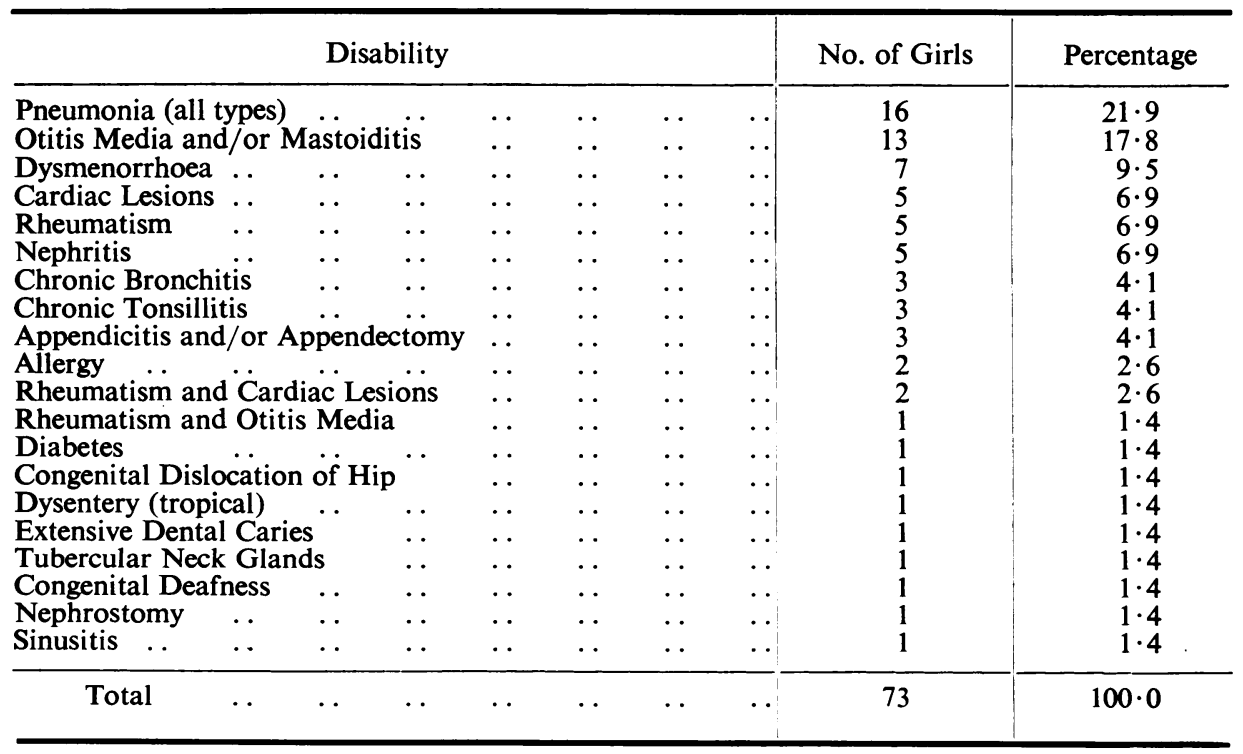


To determine the effect of a medical disability on absence, the average number of occasions of absence per pupil, excluding absences for non-medical reasons, was calculated for girls of two groups.

Group 1. With no record of medical disability.

Group 2. With a record of medical disability.

The results (Table VII) show that Group 2 had a higher absence rate in each term, although in Spring, 1948, the difference between the groups was very small.

TABLE VII

Average Number of Occasions of Absences per Pupil

\begin{tabular}{|c|c|c|c|c|c|}
\hline \multirow{2}{*}{ Group } & \multicolumn{5}{|c|}{ Term } \\
\hline & $\begin{array}{c}\text { Spring } \\
1946\end{array}$ & $\underset{1946}{\text { Autumn }}$ & $\begin{array}{l}\text { Spring } \\
1947\end{array}$ & $\underset{1947}{\text { Autumn }}$ & $\begin{array}{c}\text { Spring } \\
1948\end{array}$ \\
\hline $\begin{array}{l}1 \\
2\end{array}$ & $\begin{array}{l}1 \cdot 19 \\
1 \cdot 47\end{array}$ & $\begin{array}{l}0.95 \\
1.17\end{array}$ & $\begin{array}{l}1 \cdot 49 \\
2 \cdot 31\end{array}$ & $\begin{array}{l}1 \cdot 2 \\
1.74\end{array}$ & $\begin{array}{l}0.95 \\
0.96\end{array}$ \\
\hline Total & $1 \cdot 23$ & 0.99 & 1.65 & $1 \cdot 3$ & 0.95 \\
\hline
\end{tabular}

Physical Development and its Effect on Menarche

Table VIII, citing the average weights and heights at approximate ages, shows a spurt of growth in both mean heights and weights between the ages of 12.5 and 13.5 years. Since the mean age of menarche is 13.5 years, this spurt corresponds to the premenstrual period, and is in accordance with earlier work on the relationship of puberty to body build (Hogben and others, 1948).

To compare the physique of children of different ages, Tuxford (1942) described an index which takes into account height, weight, and chronological age. The value of the index for normal (i.e. average) physique at any age is 1.00 ; values below 1.00 indicate less than, and values above 1.00 more than, average physical development. The formula for girls is $(W \times 308-m) \div H \times 235$, where $W$ is the weight in lb., $H$ the height in inches, and $m$ the age in months. In the present communication a nomogram prepared from this formula by Campbell and Weir (1948) has been used to estimate the index; the limits of the nomogram were 0.8 and $1 \cdot 2$.

There were no girls with a Tuxford index (T.I.) of less than $0 \cdot 8$, and there were $18 \cdot 2$ per cent. with an index of more than $1 \cdot 2$. For convenience the Tuxford indices have been grouped as follows:

(A) $0 \cdot 80-0 \cdot 979$-less than normal

(B) 0.98-1.119-normal

(C) $1 \cdot 12$ and over-more than normal

Of 271 girls the percentage in each group was:
A, $29 \cdot 5$
B, $41 \cdot 5$
C, $29 \cdot 0$

Table VIII also shows the Tuxford indices for the average weights and heights at various age groups. The values for each age group from 10.5 to 14.5 inclusive are reasonably consistent; the mean value for the four observations is 1.05 . Thereafter the Tuxford 
TABLE VIII

Average Heights, Weights, and Tuxford Indices

\begin{tabular}{c|c|c|c|c}
\hline \multirow{2}{*}{$\begin{array}{c}\text { Approx. Age } \\
\text { (years) }\end{array}$} & $\begin{array}{c}\text { No. of } \\
\text { Observations }\end{array}$ & $\begin{array}{c}\text { Average } \\
\text { (lb.) }\end{array}$ & $\begin{array}{c}\text { Height } \\
\text { (in.) }\end{array}$ & $\begin{array}{c}\text { T.I. of Average } \\
\text { Weights and Heights }\end{array}$ \\
\cline { 2 - 4 } & 40 & 76 & 55.5 & 1.06 \\
11.5 & 192 & 83 & 57.3 & 1.05 \\
12.5 & 34 & 89 & 58.8 & 1.02 \\
13.5 & 14 & 103 & 60.9 & 1.05 \\
14.5 & 9 & 117 & 61.6 & 1.08 \\
15.5 & 133 & 125 & 64.1 & 1.01 \\
16.5 & 61 & 126 & 64.0 & 0.92 \\
\hline
\end{tabular}

index drops; but, as it is not intended for use in the older age groups when growth slows down, no undue significance should be attached to this downward trend.

The age of menarche was recorded at the second medical examination except in the few instances when a girl was already menstruating at the time of the first. Information regarding the age of inception was obtained in respect of 174 girls, the mean being 13.5 years. Approximately 10 per cent. of the girls were menstruating before 12.5 years and 8 per cent. did not begin until after $14 \cdot 5$ years. In Tuxford Group A, the mean age of menarche was $14 \cdot 1$, in Group B, $13 \cdot 8$, and in Group C, $12 \cdot 7$ years. The proportions of girls beginning menstruation by 13.5 years vary considerably in the three groups (Group $A$, 42 per cent.; Group B, 58 per cent.; Group C, 89 per cent.). The difference of 47 per cent. between Groups $\mathrm{A}$ and $\mathrm{C}$ has a standard deviation of approximately 10 per cent., and the odds against so large a difference occurring by chance are over 16,000 to 1 . It is therefore safe to say that there is some relationship between body build and sexual development. These results are shown in Table IX.

TABLE IX

Percentage Distribution of Ages of Menarche among Tuxford Index Groups

\begin{tabular}{|c|c|c|c|c|c|c|c|c|c|c|}
\hline \multirow{2}{*}{\multicolumn{2}{|c|}{ Tuxford Index Group }} & \multirow{2}{*}{$\begin{array}{l}\text { No. of } \\
\text { Girls }\end{array}$} & \multirow{2}{*}{$\begin{array}{l}\text { Mean } \\
\text { Age of } \\
\text { Men- } \\
\text { arche } \\
\end{array}$} & \multicolumn{6}{|c|}{ Age of Menarche (years) } & \multirow{2}{*}{$\begin{array}{l}\text { All } \\
\text { Ages }\end{array}$} \\
\hline & & & & $10 \cdot 5$ & $11 \cdot 5$ & $12 \cdot 5$ & $13 \cdot 5$ & $14 \cdot 5$ & $15 \cdot 5$ & \\
\hline $\begin{array}{l}\mathbf{A} \\
\mathbf{B} \\
\mathbf{C}\end{array}$ & $\begin{array}{l}0.8-0.979 \\
0.98-1 \cdot 119 \\
1.12 \text { and over }\end{array}$ & $\begin{array}{l}33 \\
86 \\
55\end{array}$ & $\begin{array}{l}14 \cdot 1 \\
13 \cdot 8 \\
12 \cdot 7\end{array}$ & $\frac{-}{5 \cdot 4}$ & $\begin{array}{r}3 \cdot 0 \\
1 \cdot 0 \\
22 \cdot 0\end{array}$ & $\begin{array}{r}6 \cdot 1 \\
23 \cdot 3 \\
32 \cdot 7\end{array}$ & $\begin{array}{l}33 \cdot 3 \\
33 \cdot 7 \\
29 \cdot 0\end{array}$ & $\begin{array}{r}45 \cdot 5 \\
31 \cdot 5 \\
0 \cdot 1\end{array}$ & $\begin{array}{r}12 \cdot 1 \\
10 \cdot 5 \\
1 \cdot 8\end{array}$ & $\begin{array}{l}100 \\
100 \\
100\end{array}$ \\
\hline & Total .. & 174 & $13 \cdot 5$ & $1 \cdot 7$ & $8 \cdot 0$ & $23 \cdot 3$ & $32 \cdot 0$ & $27 \cdot 0$ & $8 \cdot 0$ & 100 \\
\hline
\end{tabular}

\section{Problem of Recurrent Absenteeism}

It has been demonstrated by Greenwood and Woods (1919) and by Newbold (1926) that certain individuals are accident-prone. From an analysis of the incidence of colds among college students, Gafafer and Doull (1933) concluded that:

(a) colds are distributed by chance;

(b) in consecutive years there is a tendency for persons to remain in the same " cold-number" class;

(c) for observations separated by as long an interval as 2 years, no such constancy is detectable. 
A revaluation of Gafafer's data by Wilson and Worcester (1944), who employed a different statistical technique, led to the conclusion that the distribution of colds was not due to chance but was affected by an inter-individual variation of resistance to common cold or by some systemic influence, such as a higher exposure rate, which stimulated it among some of the persons under observation.

Analysis of the records under discussion led to the impression that certain individuals are more prone to absence than others. The records of 156 girls who were members of the school during the five school years, 1943/44 to $1947 / 48$, were therefore re-examined.

Various sub-groups of this sample are considered below, and the following schema has been devised to clarify the position at the outset. (Number of girls in each group shown in brackets.)

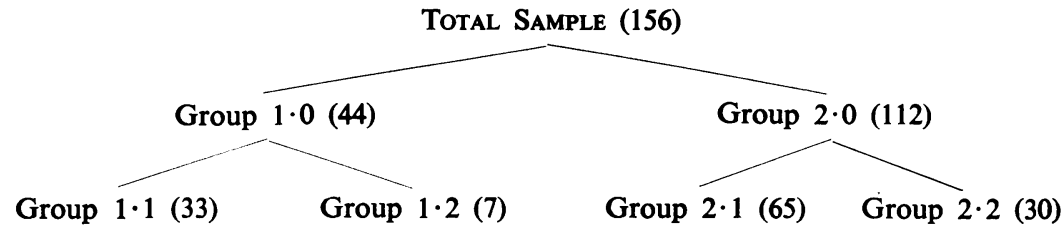

These groups may be defined as follows:

1.0 No absences at all during the Autumn term, 1943

2.0 At least one absence during the Autumn term, 1943.

$1 \cdot 1,2 \cdot 1$ No history of medical disability as defined above.

$1 \cdot 2,2 \cdot 2$ With a history of medical disability.

The division of the sample in Groups 1.0 and 2.0 was made on the purely arbitrary criterion of absence in the Autumn term, 1943, hereafter called the standard term. If the absence experience in one term is independent of that in another, we should not expect to find any significant difference with respect to absence between the groups in terms subsequent to the standard. However, if some individuals are absence-prone we might reasonably infer that they are more likely than not to be found in Group $2 \cdot 0$. It is legitimate to make such an inference only in so far as we can satisfy ourselves that our groups are alike in all respects other than absence in the selected standard term. Accordingly it is essential to compare each with its fellow with respect to the following factors, designated " criteria of homogeneity", which may have an effect on absenteeism:

(1) History of medical disability.

(2) Social class.

(3) Physique.

(4) Chronological age.

(5) Sexual age.

If no significant differences are found between Groups $1 \cdot 0$ and $2 \cdot 0$, it is justifiable to assume that, as far as is ascertainable from the available information, they are homogeneous in physical and social environments.

\section{Criteria of HomogeneIty}

(1) History of Medical Disability.-The proportion of girls in Group 1.2 was $17 \cdot 5$ per cent. of the total in Group 1.0, and in Group 2, 31.6 per cent. The standard deviation (S.D.) of the difference is 8.4 per cent. and the probability of such a difference occurring by chance is high $(0.09>P>0.08)$. However, as was shown 
earlier, medical disability has a marked effect on absence, so that comparisons will be made below between Groups $1 \cdot 1$ and $2 \cdot 1$, and Groups $1 \cdot 2$ and $2 \cdot 2$, whenever possible.

(2) Social Class.-The school population was divided into the five social classes described by the Registrar-General according to the occupation of the father. The proportion of girls in social classes I and II (i.e. professional, business executives, school teachers, senior clerical grades in Civil Service, or local government) in the two groups 1.0 and 2.0 were compared. In the former 57 per cent. and in the latter 61 per cent. came from the social classes I and II. The standard deviation of the difference is 9 per cent.; the difference, 4 per cent., is almost certainly due to chance $(P \simeq 0 \cdot 74)$.

(3) Physique.-The Tuxford index was used to measure physique. Excluding girls with a Tuxford index greater than $1 \cdot 2$, the mean index was 1.009 for Group 1.0, and 1.035 for Group $2 \cdot 0$. The difference, $0 \cdot 24$, is not significant (S.D. $=0 \cdot 186$, $P=0.85$ ). The proportion of girls with indices higher than 1.2 in Group 1.0 was not significantly different from that in Group 2.0. In the former it was 21 per cent., and in the latter, 19 per cent. (difference 2 per cent., S.D. $=8$ per cent., $P=0 \cdot 80$ ). The distribution of the girls in the two sections 1.0 and 2.0 among the three Tuxford index groups defined earlier is shown in Table X.

TABLE $X$

Effect of PhysiQue on Absence Proneness

\begin{tabular}{|c|c|c|c|c|}
\hline \multirow{3}{*}{ Tuxford Index Group } & \multicolumn{4}{|c|}{ Group } \\
\hline & \multicolumn{2}{|c|}{1} & \multicolumn{2}{|c|}{2} \\
\hline & No. & $\%$ & No. & $\%$ \\
\hline $\begin{array}{l}0.8-0.979 \\
0 \cdot 98-1 \cdot 119 \\
1 \cdot 12 \text { and over } \\
\text { Unspecified }\end{array}$ & $\begin{array}{r}13 \\
14 \\
12 \\
5\end{array}$ & $\begin{array}{l}29 \cdot 5 \\
31 \cdot 8 \\
27 \cdot 3 \\
11 \cdot 4\end{array}$ & $\begin{array}{l}18 \\
40 \\
32 \\
22\end{array}$ & $\begin{array}{l}16 \cdot 1 \\
35 \cdot 7 \\
28 \cdot 6 \\
19 \cdot 6\end{array}$ \\
\hline Total & 44 & $100 \cdot 0$ & 112 & $100 \cdot 0$ \\
\hline
\end{tabular}

(4) Chronological Age.-The mean age of girls in Group 1.0 is 12.03 years, and of those in Group 2.0 it is 11.83 years. The standard deviation of the difference is 0.305 years, and the probability of the difference $(0 \cdot 02$ years) being due to chance $0 \cdot 5$.

(5) Sexual Age.-The mean age of menarche was 13.58 years in Group 1.0 and 13.62 years in Group 2.0. The difference $(0 \cdot 04)$ is not significant (S.D. $=0 \cdot 21$ years). The distribution of the girls in the two groups among the various ages of menarche is shown in Table XI (overleaf).

If the above are accepted as tests of homogeneity, it can be said that Groups 1.0 and 2.0 are alike in these respects. If there is then any marked difference in absence experience between these two sections, these criteria may be eliminated as possible factors in its causation. The possible exception is the difference, albeit statistically insignificant, in the proportions of girls with medical disabilities in the two groups. Where possible, Sub-groups $1 \cdot 1$ and $2 \cdot 1$ will be examined separately. 
TABLE XI

Effect of Age of Menarche on Absence Proneness

\begin{tabular}{|c|c|c|c|c|}
\hline \multirow{3}{*}{$\begin{array}{l}\text { Age at Menarche } \\
\text { (years) }\end{array}$} & \multicolumn{4}{|c|}{ Group } \\
\hline & \multicolumn{2}{|c|}{1} & \multicolumn{2}{|c|}{2} \\
\hline & No. & $\%$ & No. & $\%$ \\
\hline $\begin{array}{r}10.5 \\
11.5 \\
12.5 \\
13.5 \\
14.5 \\
15.5 \\
\text { Unspecified }\end{array}$ & $\left.\begin{array}{r}-7 \\
10 \\
14 \\
10 \\
1 \\
6\end{array}\right\}$ & $\begin{array}{r}6 \cdot 9 \\
6 \cdot 9 \\
22 \cdot 7 \\
31 \cdot 8 \\
22 \cdot 7 \\
2 \cdot 3 \\
13 \cdot 6\end{array}$ & $\left.\begin{array}{r}2 \\
6 \\
16 \\
29 \\
20 \\
8 \\
31\end{array}\right\}$ & $\begin{array}{r}1 \cdot 8 \\
5 \cdot 4 \\
14 \cdot 3 \\
25 \cdot 9 \\
17 \cdot 9 \\
7 \cdot 1 \\
27 \cdot 6\end{array}$ \\
\hline Total & 44 & $100 \cdot 0$ & 112 & $100 \cdot 0$ \\
\hline
\end{tabular}

The classes with small numbers are grouped together as bracketed.

$\chi^{2}=3 \cdot 907$. d.f. $=3$. $0 \cdot 3>P>0.2$.

The absence experience of Groups 1.0 and 2.0 was compared by recourse to the following yardsticks:

(1) The mean number of absences per term per pupil.

(2) The distribution of girls among various absence-classes.

(Girls who have no absences in a specified term are included in the 0-absence class, those with one absence in the 1-absence class, etc.)

(3) The distribution of the number of terms completely free from absence after the standard term.

(4) The correlation of the number of absences experienced in one term with that in another.

ABSENCES PER PUPIL.-The mean number of occasions of absence per pupil in each term are shown in Table XII and Fig. 2. The means are shown for each of the Groups $1 \cdot 0$ and $2 \cdot 0$, and for each of the Sub-groups $1 \cdot 1,2 \cdot 1,1 \cdot 2,2 \cdot 2$. In every instance except one the mean number of absences in Group 2.0 and its sub-groups

TABLE XII

Mean Number of Occasions of Absence

\begin{tabular}{|c|c|c|c|c|c|}
\hline \multirow{2}{*}{ Group } & \multirow{2}{*}{$\begin{array}{l}\text { No. of } \\
\text { Pupils }\end{array}$} & \multicolumn{4}{|c|}{ Term } \\
\hline & & 1944 & 1945 & 1946 & 1947 \\
\hline $\begin{array}{l}1 \cdot 0 \\
2 \cdot 0\end{array}$ & $\begin{array}{r}44 \\
110\end{array}$ & $\begin{array}{l}0.568 \\
1 \cdot 3\end{array}$ & $\begin{array}{l}0.659 \\
1.444\end{array}$ & $\begin{array}{l}0 \cdot 818 \\
1 \cdot 241\end{array}$ & $\begin{array}{l}1 \cdot 114 \\
1 \cdot 509\end{array}$ \\
\hline $\begin{array}{l}1 \cdot 1 \\
2 \cdot 1\end{array}$ & $\begin{array}{l}33 \\
65\end{array}$ & $\begin{array}{l}0.567 \\
1 \cdot 19\end{array}$ & $\begin{array}{l}0.515 \\
0.908\end{array}$ & $\begin{array}{l}0 \cdot 808 \\
1 \cdot 108\end{array}$ & $\begin{array}{l}0.909 \\
1.27\end{array}$ \\
\hline $\begin{array}{l}1 \cdot 2 \\
2 \cdot 2\end{array}$ & $\begin{array}{r}7 \\
30\end{array}$ & $\begin{array}{l}0.857 \\
1.7\end{array}$ & $\begin{array}{l}1 \cdot 143 \\
1 \cdot 896\end{array}$ & $\begin{array}{l}1 \cdot 0 \\
1.667\end{array}$ & $\begin{array}{l}2 \cdot 285 \\
1.953\end{array}$ \\
\hline
\end{tabular}


O: Whole section

1: No medical disability

2: Medicol disobility

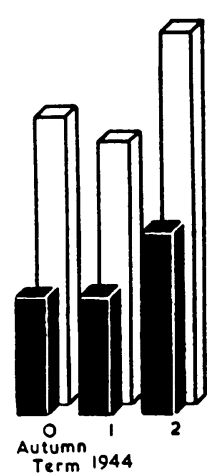

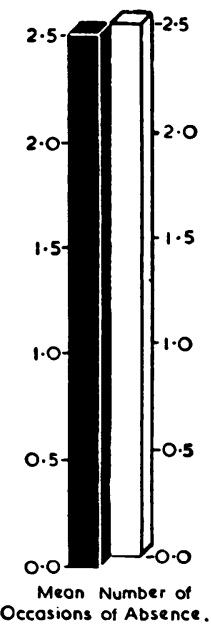

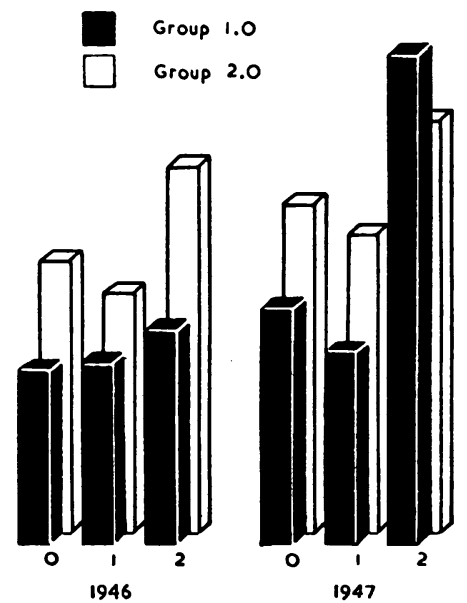

FIG. 2.-Comparison of mean number of occasions of absence from all causes in Groups 1.0 and $2 \cdot 0$.

is greater than that in Group 1.0 and its sub-groups. In view of the small numbers in Group $1 \cdot 0$, and particularly in its Sub-group $1 \cdot 2$, this constancy is remarkable.

EFFECT OF DisABILITY.-Each group was investigated in the four Autumn terms following Autumn, 1943, to determine the frequency with which girls of either group came into the various absence-classes. The problem can be stated thus:

What proportion of girls in Group 1.0 had no absences at all in the Autumn term, 1944, or 1945, etc., and was this proportion significantly different from that in Group 2:0 ?

If we assume that the members of either group are equally liable to absence then we should not expect to find a significant difference between the groups with respect to the distribution in the various absence classes. Fig. 3 and Table XIII (overleaf) show that the frequency distributions of the various absence-classes in Groups $1 \cdot 0$ and $2 \cdot 0$ are significantly different.
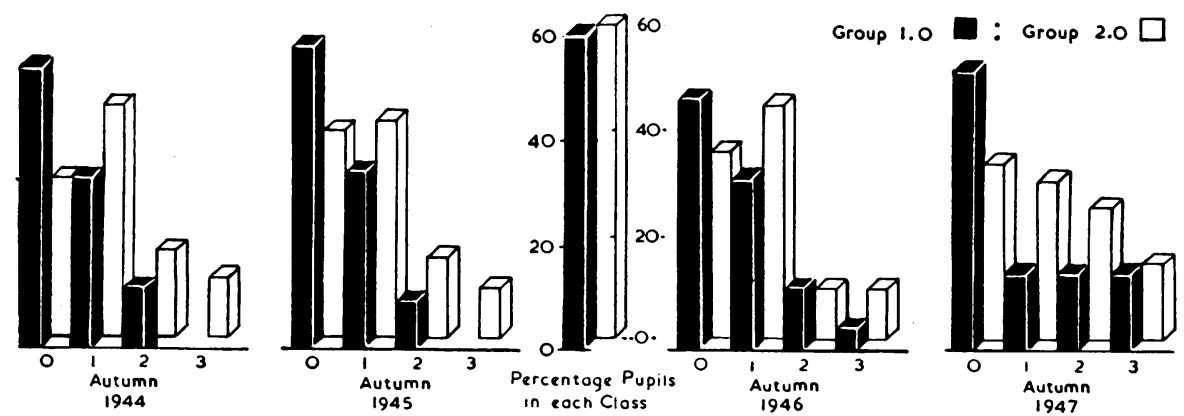

Fig. 3.-Percentage distribution of girls in the absence classes (0-3) in Groups 1.0 and 2.0 . 
TABLE XIII

Percentage Distribution of Girls among the Various Absence classes Comparing Group 1.0 with $2 \cdot 0$, and Group $1 \cdot 1$ with $2 \cdot 1$

\begin{tabular}{|c|c|c|c|c|c|c|c|c|c|}
\hline \multirow{2}{*}{$\begin{array}{c}\text { Autumn } \\
\text { Term }\end{array}$} & \multirow{2}{*}{ Group } & \multicolumn{7}{|c|}{ Percentage Frequency of each Absence Class } & \multirow{2}{*}{ Remarks } \\
\hline & & 0 & 1 & 2 & 3. & 4 & 5 & 6 & \\
\hline \multirow{2}{*}{1944} & $\begin{array}{l}1 \cdot 0 \\
2 \cdot 0\end{array}$ & $\begin{array}{l}59 \cdot 1 \\
23 \cdot 6\end{array}$ & $\begin{array}{l}29 \cdot 5 \\
41 \cdot 8\end{array}$ & $\begin{array}{r}9 \cdot 1 \\
19 \cdot 1\end{array}$ & $\overline{11 \cdot 8}$ & $\begin{array}{l}2 \cdot 3 \\
3 \cdot 6\end{array}$ & - & - & $\begin{array}{l}\chi^{2}=18 \cdot 97 \\
0 \cdot 001>P\end{array}$ \\
\hline & $\begin{array}{l}1 \cdot 1 \\
2 \cdot 1\end{array}$ & $\begin{array}{l}54 \cdot 5 \\
28 \cdot 6\end{array}$ & $\begin{array}{l}33 \cdot 3 \\
42 \cdot 9\end{array}$ & $\begin{array}{l}12 \cdot 1 \\
14 \cdot 3\end{array}$ & $\overline{9 \cdot 5}$ & $\overline{4 \cdot 8}$ & - & - & $\begin{array}{l}\chi^{2}=6.949 \\
0.05>P>0.02\end{array}$ \\
\hline \multirow{2}{*}{1945} & $\begin{array}{l}1 \cdot 0 \\
2 \cdot 0\end{array}$ & $\begin{array}{l}50 \cdot 0 \\
36 \cdot 9\end{array}$ & $\begin{array}{l}38 \cdot 6 \\
34 \cdot 3\end{array}$ & $\begin{array}{r}9 \cdot 1 \\
12 \cdot 6\end{array}$ & $\overline{11 \cdot 7}$ & $\begin{array}{l}2 \cdot 3 \\
2 \cdot 7\end{array}$ & $\overline{1 \cdot 8}$ & - & $\begin{array}{l}\chi^{2}=6.732 \\
0.05>P>0.02\end{array}$ \\
\hline & $\begin{array}{l}1 \cdot 1 \\
2 \cdot 1\end{array}$ & $\begin{array}{l}57 \cdot 6 \\
38 \cdot 4\end{array}$ & $\begin{array}{l}33 \cdot 3 \\
40 \cdot 0\end{array}$ & $\begin{array}{r}9 \cdot 1 \\
13 \cdot 8\end{array}$ & $\overline{7 \cdot 7}$ & - & 二 & - & $\begin{array}{l}\chi^{2}=4 \cdot 467 \\
0 \cdot 2>P>0 \cdot 1\end{array}$ \\
\hline \multirow{2}{*}{1946} & $\begin{array}{l}1 \cdot 0 \\
2 \cdot 0\end{array}$ & $\begin{array}{l}52 \cdot 3 \\
33 \cdot 0\end{array}$ & $\begin{array}{l}29 \cdot 5 \\
33 \cdot 9\end{array}$ & $\begin{array}{r}9 \cdot 1 \\
16 \cdot 1\end{array}$ & $\begin{array}{r}6 \cdot 8 \\
12 \cdot 5\end{array}$ & $\overline{1 \cdot 8}$ & $\overline{2 \cdot 7}$ & $\frac{2 \cdot 3}{-}$ & $\begin{array}{l}\chi^{2}=5.642 \\
0.1>P>0.05\end{array}$ \\
\hline & $\begin{array}{l}1 \cdot 1 \\
2 \cdot 1\end{array}$ & $\begin{array}{l}48 \cdot 5 \\
33 \cdot 8\end{array}$ & $\begin{array}{l}33 \cdot 3 \\
43 \cdot 1\end{array}$ & $\begin{array}{r}12 \cdot 1 \\
9 \cdot 2\end{array}$ & $\begin{array}{l}3 \cdot 0 \\
9 \cdot 2\end{array}$ & $\overline{1 \cdot 5}$ & $\overline{3 \cdot 1}$ & $3 \cdot 0$ & $\begin{array}{l}\chi^{2}=1.977 \\
0.7>P>0.5\end{array}$ \\
\hline \multirow{2}{*}{1947} & $\begin{array}{l}1 \cdot 0 \\
2 \cdot 0\end{array}$ & $\begin{array}{l}47 \cdot 4 \\
24 \cdot 5\end{array}$ & $\begin{array}{l}15 \cdot 9 \\
29 \cdot 1\end{array}$ & $\begin{array}{l}15 \cdot 9 \\
24 \cdot 5\end{array}$ & $\begin{array}{l}18 \cdot 2 \\
17 \cdot 3\end{array}$ & $\begin{array}{l}2 \cdot 3 \\
2 \cdot 7\end{array}$ & $\overline{0.9}$ & $\overline{0.9}$ & $\begin{array}{l}\chi^{2}=8 \cdot 663 \\
0.05>P>0.02\end{array}$ \\
\hline & $\begin{array}{l}1 \cdot 1 \\
2 \cdot 1\end{array}$ & $\begin{array}{l}54 \cdot 5 \\
31 \cdot 7\end{array}$ & $\begin{array}{l}15 \cdot 2 \\
28 \cdot 6\end{array}$ & $\begin{array}{l}15 \cdot 2 \\
23 \cdot 8\end{array}$ & $\begin{array}{l}15 \cdot 2 \\
12 \cdot 7\end{array}$ & $\overline{3 \cdot 2}$ & - & - & $\begin{array}{l}\chi^{2}=5.017 \\
0.1>P>0.05\end{array}$ \\
\hline
\end{tabular}

When the Sub-groups $1 \cdot 1$ and $2 \cdot 1$ are considered (i.e. the girls with no history of medical disability) the distributions in the last three terms are not significantly different. This result is probably due in part to the small numbers in the higher absence groups. If we consider the proportions for the four terms in the 0 -absence class only, we get the results set out in Table XIV. The proportionate differences in the 0-absence class are significant for all groups in all terms except Autumn, 1945, and Autumn, 1946.

TABLE XIV

Percentage of Girls with Perfect Attendance in Various Terms (Comparing Groups 1.0 and $2 \cdot 0$, and Groups $1 \cdot 1$ and $2 \cdot 1$ )

\begin{tabular}{|c|c|c|c|c|}
\hline \multirow{2}{*}{$\begin{array}{c}\text { Autumn Term } \\
1944 \\
1945 \\
1946 \\
1947\end{array}$} & \multicolumn{2}{|c|}{ Percentage in 0-Absence Class } & \multirow{2}{*}{$\begin{array}{r}\text { S.D. } \\
8 \cdot 4 \\
13 \cdot 0 \\
19 \cdot 3 \\
23 \cdot 2\end{array}$} & \multirow{2}{*}{$\begin{array}{c}P \\
0.0001>P>0.00001 \\
0.14>P>0.13 \\
0.01>P>0.02 \\
0.001>P>0.01\end{array}$} \\
\hline & $\begin{array}{c}\text { Group } 1 \cdot 0 \\
59 \cdot 1 \\
50 \cdot 0 \\
52 \cdot 3 \\
47 \cdot 7\end{array}$ & $\begin{array}{c}\text { Group } 2 \cdot 0 \\
23 \cdot 6 \\
36 \cdot 9 \\
33 \cdot 0 \\
24 \cdot 5\end{array}$ & & \\
\hline $\begin{array}{l}1944 \\
1945 \\
1946 \\
1947\end{array}$ & $\begin{array}{c}\text { Group } 1 \cdot 1 \\
54 \cdot 5 \\
57 \cdot 6 \\
48 \cdot 5 \\
54 \cdot 5\end{array}$ & $\begin{array}{c}\text { Group } 2 \cdot 1 \\
28 \cdot 6 \\
38 \cdot 4 \\
33 \cdot 8 \\
31 \cdot 7\end{array}$ & $\begin{array}{l}10 \cdot 3 \\
10 \cdot 6 \\
10 \cdot 4 \\
10 \cdot 5\end{array}$ & $\begin{array}{r}0.02>P>0.01 \\
0.1>P>0.05 \\
P=0.18 \\
0.04>P>0.03\end{array}$ \\
\hline
\end{tabular}


Each girl of the sample remained at school for a further five Spring and four Autumn terms. The total number of terms after the standard term experienced by girls in Group 1.0 was $396(=9 \times 44)$, and $1,008(=9 \times 112)$ for Group $2 \cdot 0$. If no girl in either section had any absence during the whole nine terms, there would be 396 terms of perfect attendance in Group 1.0, and 1,008 in Group 2.0. Table $\mathrm{XV}$ shows the frequency with which girls in the various groups experienced $0,1, \ldots$ 9 terms of perfect attendance, and that there are significant differences between the frequency distribution of the two groups. We can also determine the proportion of terms in which there was perfect attendance for the two groups (Table XVI).

TABLE XV

Frequency Distribution showing Number of Girls with $x$ Terms of Perfect Attendance (WHERE $x$ LIES WITHIN THE LIMITS $0-9$ )

\begin{tabular}{|c|c|c|c|c|c|c|c|c|c|c|c|c|}
\hline \multirow{2}{*}{ Group } & \multirow{2}{*}{$\begin{array}{l}\text { No. of } \\
\text { Girls }\end{array}$} & \multicolumn{10}{|c|}{ Number of Terms $(x)$} & \multirow{2}{*}{ Remarks } \\
\hline & & 0 & 1 & 2 & 3 & 4 & 5 & 6 & 7 & 8 & 9 & \\
\hline $1 \cdot 0$ & 44 & 2 & 5 & 7 & 5 & 8 & 6 & 2 & 6 & 2 & 1 & $\chi^{2}=13 \cdot 7$ \\
\hline $2 \cdot 0$ & 112 & 22 & 18 & 26 & 11 & 11 & 15 & 6 & 3 & 一 & - & $0.02>P>0.01$ \\
\hline $1 \cdot 1$ & 36 & 1 & 5 & 6 & 3 & 6 & 5 & 2 & 6 & 2 & - & $\chi^{2}=7 \cdot 46$ \\
\hline $2 \cdot 1$ & 65 & 9 & 10 & 14 & 9 & 7 & 10 & 4 & 2 & - & - & $P=0.05$ \\
\hline
\end{tabular}

Note.-To use the $\chi$-squared test in this instance it was necessary to group together $x=0$ and 1 ; and $x=6,7,8$, and 9 .

TABLE XVI

Comparison of Various Groups as regards Percentage of Terms of Perfect Attendance

\begin{tabular}{|c|c|c|c|c|c|c|}
\hline \multirow{3}{*}{ Group } & \multicolumn{3}{|c|}{ Number of Terms: } & \multirow{3}{*}{$\begin{array}{c}\text { Difference } \\
\text { per cent. }\end{array}$} & \multirow{3}{*}{$\begin{array}{l}\text { Standard } \\
\text { Deviation } \\
\text { per cent. }\end{array}$} & \multirow{3}{*}{$P$} \\
\hline & \multirow{2}{*}{ Experienced } & \multicolumn{2}{|c|}{ With Perfect Attendance } & & & \\
\hline & & Number & Per cent. & & & \\
\hline $1 \cdot 0$ & 396 & 175 & 44 & \multirow{2}{*}{$\begin{array}{l}16 \\
.\end{array}$} & \multirow{2}{*}{$2 \cdot 7$} & \multirow{2}{*}{$\cdot 0^{7} 1$} \\
\hline $2 \cdot 0$ & 1,008 & 279 & 28 & & & \\
\hline $1 \cdot 1$ & 324 & 145 & 45 & \multirow{2}{*}{14} & \multirow{2}{*}{$2 \cdot 0$} & \multirow{2}{*}{$\cdot 0^{8} 1$} \\
\hline $2 \cdot 1$ & 585 & 179 & 31 & & & \\
\hline
\end{tabular}

There can be little doubt about the significance of the difference between the groups in this respect; but the absence experiences of the two groups separately and together can also be investigated by determining the correlation between the number of absences incurred by each girl in Spring, 1944, and the number she incurred during subsequent Spring terms. If the absence experience in one term were independent of that in another, correlation between the two sets of paired observations would not exist and the correlation ratio would be zero, or would not differ significantly from it. In Group 1.0 the only term in which the absence 
experience was significantly correlated with that of Spring term, 1944, was the Spring term, 1947, during which term there were epidemics of German measles, measles, and scarlet fever. In Group 2.0 significant correlation ratios were obtained for three terms. When the two groups are merged together the absence in every term is significantly correlated with that in Spring, 1944. These results are shown in Table XVII.

TABLE XVII

Correlation Ratios for the Number of Absences in Various Terms with that in Standard TERM, SPRING 1944

\begin{tabular}{|c|c|c|c|c|c|}
\hline \multirow{2}{*}{ Group } & \multirow{2}{*}{ No. of Girls } & \multicolumn{4}{|c|}{ Spring Term } \\
\hline & & 1945 & 1946 & 1947 & 1948 \\
\hline $1 \cdot 0$ & 44 & $\begin{array}{c}0.041 \\
P>0.9\end{array}$ & $\begin{array}{c}0.203 \\
0 \cdot 2>P>0 \cdot 1\end{array}$ & $\begin{array}{c}0.383 \\
0.01>P\end{array}$ & $\begin{array}{c}0.242 \\
0.1>P>0.05\end{array}$ \\
\hline $2 \cdot 0$ & 112 & $\begin{array}{c}0.314 \\
0.001>P\end{array}$ & $\begin{array}{c}0 \cdot 150 \\
0 \cdot 2>P>0 \cdot 1\end{array}$ & $\begin{array}{c}0.212 \\
P=0.02\end{array}$ & $\begin{array}{c}0.188 \\
0.05>P>0.02\end{array}$ \\
\hline Both & 156 & $\begin{array}{c}0.213 \\
0.001>P\end{array}$ & $\begin{array}{c}0.172 \\
0.02>P>0.01\end{array}$ & $\begin{array}{c}0 \cdot 27 \\
0.01>P\end{array}$ & $\begin{array}{c}0.211 \\
0.001>P\end{array}$ \\
\hline
\end{tabular}

The effects of social class and the number of siblings in the pupils' families were assessed by correlation. The social classes were each given a numerical value in accordance with their designation (e.g. Social Class $I=1$, etc.). The mean number of absences per pupil per term was determined using the data of ten terms. The number of siblings in each family was likewise correlated with the mean number of absences (Table XVIII). In neither instance is the correlation ratio significantly different from zero.

TABLE XVIII

Effect on Absence of Social Class and Size of Family

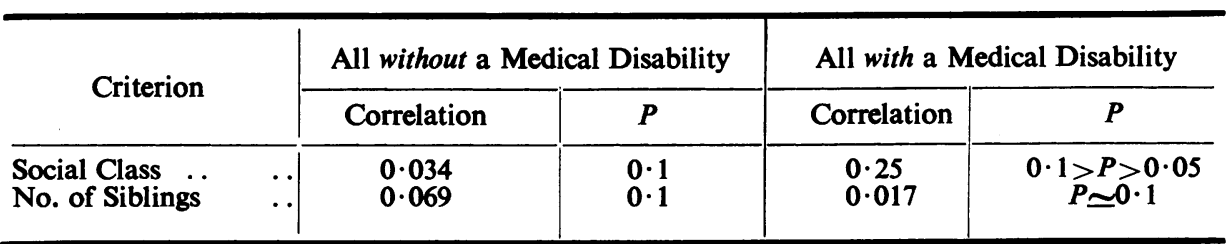

Discussion of Absence Proneness.-Both the methods employed above give rise to the following conclusions:

(i) Individuals are not alike in their proneness to absence.

(ii) Notwithstanding the small samples examined, it is reasonable to assume that this proneness lasts in some cases at least as long as 5 years. 
(iii) Although there is a prima facie case for considering medical disability to be a major factor in the absence proneness, further study indicates that it is not the only cause of recurrent absence and that in this survey absence proneness could not be attributed to any single cause.

It has been shown earlier that 42 per cent. of the total absences were specified as due to respiratory disease. In addition, no cause was specified for about 25 per cent. of all absences, and it is likely that a high proportion of these unspecified absences were also due to respiratory disease. It might well be that this absence proneness is due to the fact that certain individuals are more susceptible to colds than others (Wilson and Worcester, 1944), or to the fact that individuals respond to adverse circumstances in different ways.

Habitual truancy can be reasonably discounted in a school of this type; but a conscientious child, who would never dream of wilfully absenting herself from school to avoid an unpleasant experience, might be kept at home because of an opportunely-timed headache, bilious attack, or cold. Such psychosomatic disturbances are not uncommon, and most people must have experienced at some time an ailment which conveniently enabled them to avoid an unpleasant duty. Occurrences which appear trivial to adults often make sensitive children miserable. Recourse to absenteeism to avoid unwelcome contacts may thus produce a disposition to deal with problems by evasion instead of resolution. In schoolchildren it is therefore of some importance to observe those who are frequently absent, no matter how short the duration. Absences due to respiratory disease may indicate that the child is in the early stages of tuberculosis or bronchiectasis; fatigue and debility may indicate anaemia, malnutrition, diabetes, or some serious organic disease. On the other hand, any one set of recurrent symptoms not explicable in terms of organic medicine may show that the child is maladjusted to the school environment, and a sympathetic investigation may elicit a cause which can easily be eradicated. The important fact to recognize is that recurrent absences from school can be regarded as a symptom of some mental or physical disharmony; to treat it in time may decrease the morbidity of organic disease, or the incidence of psychoneurosis and juvenile delinquency.

\section{Detection of Absence Proneness}

Many schools maintain separate progress cards for each individual, which show the academic, athletic, and social progress throughout the school; but few schools maintain individual absence record cards. Thus no such case history is available to the school doctor, who rarely has sufficient time to make regular thorough medical examinations of every pupil. The provision of a card showing details of the duration and cause of every absence would prove useful as a guide to history-taking, and would put the school doctor in a position to sift out those children likely to require more detailed examination.

The need for time-saving devices in the case-history taking at school medical examinations was discussed by Gordon (1947), and the usefulness of school 
morbidity records as an index of the health of schoolchildren has been stressed in America by several authors, including Downes (1945), and Collins (1928) who writes:

The school sickness record would serve the double purpose of a continuous record of the health of the child and a criterion for referring children for special examination. Any child who suffers frequent attacks of illness which entail absence from school may well be referred for examination, even though the condition is only a headache, for it will enable the physician to discover in their early and preventable stages physical impairments which otherwise might be serious.

It would therefore seem to be desirable that every absence from school should be accounted for by a note, from the parents if the duration is less than one week, or from a doctor if it is longer. The teacher should enter the duration in days and the cause as in the sample record shown in Fig. 4, a postscript $(D)$ or $(P)$ showing

\begin{tabular}{|c|c|c|c|c|c|c|c|c|c|c|c|c|c|c|c|c|c|c|}
\hline \multirow{2}{*}{\multicolumn{2}{|c|}{ NAME }} & \multicolumn{4}{|c|}{ DATE OF BIRTH } & \multicolumn{4}{|c|}{ DATE OF ENTRY } & \multicolumn{4}{|c|}{ FORM OF ENTRY } & \multicolumn{5}{|c|}{ OCCUPATION OF FATHER } \\
\hline & & \multicolumn{4}{|c|}{ SCHOOL NUMBER } & \multicolumn{8}{|c|}{ PREVIOUS SCHOOL } & \multicolumn{5}{|c|}{ ADDRESS } \\
\hline FORM & DATE WEEK OR TERM & 1 & 2 & 3 & 4 & 5 & 6 & 7 & 8 & 9 & 10 & 11 & 12 & 13 & 14 & 15 & $P A$ & SUMMARY \\
\hline & & & & & & & & & & & & & & & & & $X$ & \\
\hline & & & & 5 & (D) & & & & & & & & & & & & & \\
\hline & & & & $\begin{array}{l}\bar{T} \\
\text { Head }\end{array}$ & oche & (p) & & & & & & & & & & mert & & \\
\hline & & & & & & & & & & & & & & & & & & \\
\hline & & & & & & & & & & & & & & & & & & \\
\hline & & & & & & & & & & & & & & & & & & \\
\hline & & & & & & & & & & & & & & & & & & \\
\hline & & & & & & & & & & & & & & & & & & \\
\hline & & & & & & & & & & & & & & & & & & \\
\hline
\end{tabular}

Fig. 4.-Absence record card.

whether the note was from doctor or parents. The column headed P.A. should be marked $X$ at the end of the term if the child has had perfect attendance, otherwise $O$. In this manner a continuous record of the child's absences could be maintained with little more effort than the existing systems entail. Records of this type would enable teachers to pick out children who need a medical examination before the appointed time. If the school absence records were standardized, valuable information could be obtained in the younger age groups respecting:

(1) incidence of various diseases,

(2) estimations of case mortality rates,

(3) health of school populations in different environments.

\section{SUMMARY}

(1) The absence and medical records of a large grammar school for girls have been analysed. 
(2) The ca usation of absences incurred by the girls has been examined. The importance of respiratory disease as a cause of absence is discussed.

(3) The association of sexual age with physical development is noted.

(4) It is found that some girls, regardless of their medical history, social environment, or physique, have a predisposition to recurrent absences. This has been called " absence proneness" by analogy with accident proneness.

(5) The possible causation of absence proneness is discussed.

(6) A method of detection of absence proneness by improved school absence records is suggested.

This enquiry was undertaken while I was in receipt of a grant from the Halley Stewart Trust, to which my thanks are due. I should like to take this opportunity of recording my gratitude to the Headmistress of the selected school for making available to me the records used in this survey.

\section{REFERENCES}

Campbell, F. W., and Weir, J. B. de V. (1948). Brit. J. Nutrit., 2, 119.

Collins, S. D. (1928). “ Trans. 5th Annual Meeting Amer. Child Hith Ass.”, p. 149.

Downes, J. (1945). Amer. J. publ. Hlth, 65, 593.

Gafafer, W. M., and Doull, J. A. (1933). Amer. J. Hyg., 18, 712.

Gordon, I. (1947). British Journal of Social Medicine, 1, 238.

Greenwood, M., and Woods, H. (1919). " Industrial Fatigue Research Board, Rep. No. 4 ". H.M.S.O., London.

Hogben, H., Waterhouse, J. A. H., and Hogben, L. (1948). British Journal of Social Medicine, 2, 29. Newbold, E. M. (1926). “ "Industrial Fatigue Research Board, Rep. No. 34." H.M.S.O., London.

Tuxford, A. W. (1942). J. Hyg., Camb., 42, 549.

Wilson, E. B., and Worcester, J. (1944). Science, 99, 468. 